\title{
Ontogenetic changes in hyposaline tolerance in the mussels Mytilus edulis and M. trossulus: implications for distribution
}

\author{
Jian-Wen Qiu ${ }^{1}$, Réjean Tremblay ${ }^{2}$, Edwin Bourget ${ }^{1, *}$ \\ ${ }^{1}$ GIROQ, Départment de Biologie, Université Laval, Québec G1K 7P4, Canada \\ ${ }^{2}$ Centre Aquicole Marin, Ministère de l'Agriculture, des Pêcheries et de l'Alimentation du Québec, Rue du Parc, \\ Grande-Rivière, Québec G1C 1V0, Canada
}

\begin{abstract}
The effect of salinity (5 to $25 \mathrm{ppt}$ ) on Mytilus edulis and $M$. trossulus that co-exist in Atlantic Canada was examined in 2 laboratory experiments. The first experiment tested the effect of salinity on survival and duration of development from fertilization to settlement in the 2 species. Hyposalinity reduced survivorship and percent metamorphosis, and lengthened duration of development. At 5 and $10 \mathrm{ppt}$, all early stages of both species died. At $25 \mathrm{ppt},>90 \%$ of individuals of both species survived through the oocyte to swimming embryo and swimming embryo to D-veliger stages, but only ca. $40 \%$ survived through the D-veliger to eyed-veliger stage, and 30 to $42 \%$ of eyed-veligers successfully metamorphosed. At 15 ppt, the 2 species significantly differed in survival rate, duration of development, and metamorphosis. $M$. edulis did not develop through any of the 3 stages from oocyte to eyed-veliger. No $M$. edulis eyed-veligers metamorphosed. In contrast, in $M$. trossulus, $26 \%$ of oocytes and $15 \%$ of swimming embryos developed into swimming embryos and D-veligers, respectively, and $13 \%$ of eyedveligers metamorphosed into plantigrades. At 20 ppt, some $M$. edulis developed through each of the 4 stages, but the development time was longer and there was a lower percentage than for the corresponding stage of $M$. trossulus. The second experiment examined the effect of salinity on survival of juveniles and adults. The 2 species responded to hyposaline stress similarly. Survival ranged from 0 at $5 \mathrm{ppt}$ to $100 \%$ at 20 to $25 \mathrm{ppt}$. At $10 \mathrm{ppt}$, reproductive status affected mortality, with <5\% mortality in juveniles and post-spawning individuals, but 60 to $67 \%$ mortality in reproductive mussels. A similar situation occurred at $15 \mathrm{ppt}$ except there was lower mortality for reproductive individuals. Thus, we found that only in the early ontogenetic stages was $M$. edulis less tolerant to low salinity stress than $M$. trossulus. Such difference suggests that selective mortality against $M$. edulis in early ontogenetic stages rather than post-settlement stage may be responsible for the persistence of a few pure $M$. trossulus populations along the Gaspé Peninsula. We also found that the ability to tolerate hyposalinity was weakened during the reproductive period, which indicates that salinity may also act as a selective factor in determining the abundance and size structure of wild mussel populations.
\end{abstract}

KEY WORDS: Mussel $\cdot$ Mytilus $\cdot$ Salinity $\cdot$ Ontogeny $\cdot$ Life cycle

Resale or republication not permitted without written consent of the publisher

\section{INTRODUCTION}

The life cycle of a mussel consists of an embryonic stage, a trochophore larval stage, a veliger larval stage,

\footnotetext{
*Corresponding author. Present address: Université de Sherbrooke, Sherbrooke J1R 2R1, Canada.

E-mail: edwin.bourget@rectorat.usherb.ca
}

and an adult stage. The adults of Mytilus edulis L. are euryhaline, but in the inner Baltic Sea at 4 to $5 \mathrm{ppt}$ salinity they grow slowly and reach a small maximum size (Remane 1971). Several laboratory studies have reported on the salinity tolerance of early stages of M. edulis. The fertilization proceeded normally over a range of 15 to $40 \mathrm{ppt}$, and development to the trochophore stage occurred from 30 to 40 ppt (Bayne 1965). 
Veliger larvae from adults collected from different localities varied in their tolerance to low salinities: growth began to decline at 24 ppt for larvae from Anglesey (North Wales), but larvae from Helsingør (Denmark), could grow even at 14 to 14.5 ppt (Bayne 1965). Over $70 \%$ of the larvae from Milford (Connecticut, USA) survived over a wide salinity range (15 to $40 \mathrm{ppt})$; growth began to decline at $20 \mathrm{ppt}$, but was still $>50 \%$ of the maximum at 15 ppt (Hrs-Brenko \& Calabrese 1969). These studies indicate that different developmental stages and populations of $M$. edulis vary in their tolerance to low salinity. In contrast to embryonic development, which requires relatively high salinity, fertilization, larval development and adult growth can occur over a considerably wide range. The ability to tolerate salinity fluctuation was believed to explain the euryhaline distribution of M. edulis (Widdows 1991).

The re-discovery of Mytilus trossulus Gould (Theisen 1978, Koehn et al. 1984, Varvio et al. 1988, McDonald et al. 1991) prompted us to re-examine these early studies on hyposaline tolerance in mussels. The distribution pattern of the 2 species (Väinölä \& Hvilsom 1991, Gosling 1992) indicates that the mussels in Remane (1971), collected from the Baltic Sea, were probably $M$. trossulus. The mussels from Anglesey were probably $M$. edulis, but the Helsingør population was from the transition zone between the $M$. edulis population in Kattegat and the M. trossulus population in the Baltic Sea and could be either of the 2 species (Bayne 1965). The dissimilar tolerance by the larvae from these 2 populations could be a result of $M$. trossulus being more tolerant to low salinity or $M$. edulis adults adapted to low salinity being able to produce larvae that were more tolerant.

Mixed populations of Mytilus edulis and $M$. trossulus co-exist in Atlantic Canada (Varvio et al. 1988, Koehn 1991, Gosling 1992, Innes et al. 1999, Mallet \& Carver 1999). Pure M. trossulus populations have also been found in this area, inhabiting Bras d'Or Lakes (Nova Scotia), a semi-enclosed water body connected with the open ocean through 3 narrow tidal channels (Krauel 1975, Mallet \& Carver 1999), as well as the river mouths of Baie des BellesAmours, Baie de Jacques-Cartier, Baie de Gaspé, and Rivière-au-Renard in Québec (Thomas et al. 2000; Fig. 1). Maintenance of a pure population of M. trossulus adults requires environmental conditions favorable for sur- vival of all its life stages and no invasion of external $M$. edulis larvae or environmental conditions not suitable for the survival of $M$. edulis. Assuming a 1 mo larval development (Bayne 1965) and a net current velocity of $5 \mathrm{~cm} \mathrm{~s}^{-1}$, which is common along the shores of Québec (Huntsman et al. 1954, El-Sabh 1976), a mussel larva can drift for ca. $130 \mathrm{~km}$ before reaching competency to settle. A competent mussel larva can delay metamorphosis for up to $45 \mathrm{~d}$ if no suitable substratum is encountered (Pechenik 1990), making a longer dispersal distance possible. While the pure population of $M$. trossulus in Bras d'Or Lakes could be selfsustained, external mussel larvae could easily invade the populations in the river mouths noted above. The potential external larval supply would not be monospecific since both species fall within $130 \mathrm{~km}$ of the river mouths where there is no effective geographical barrier to exclude external larval migrants. This distribution pattern suggests that $M$. edulis may be more vulnerable to hyposaline stress than $M$. trossulus. The absence of adult $M$. edulis in these populations of $M$. trossulus may be the result of selective mortality against $M$. edulis at any of the developmental stages from gamete to juvenile.

We investigated the effect of hyposaline stress on the early development of both mussel species using ontogenetic stages reared in the laboratory. We also compared the sensitivity of juveniles and adults of both species to hyposaline stress using individuals collected from the field. The aim of this study was to test whether

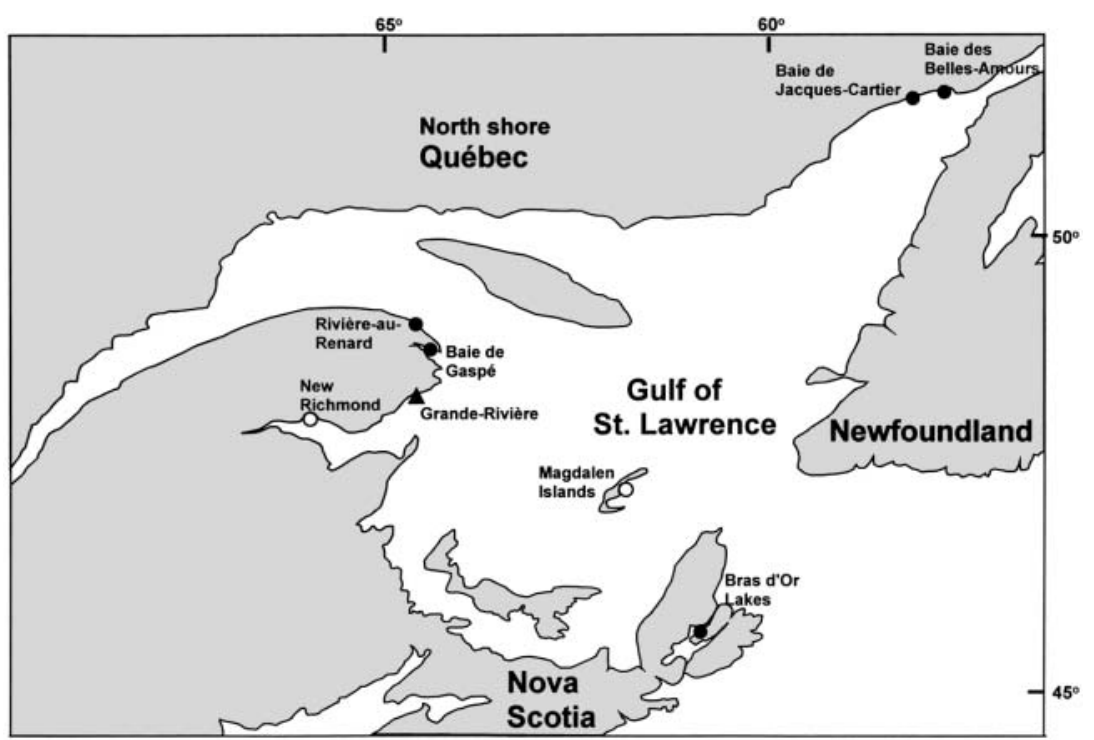

Fig. 1. Map of Gulf of St. Lawrence showing populations of Mytilus trossulus (•) in Bras d'Or Lakes, Baie des Belles-Amours, Baie de Jacques-Cartier, Rivièreau-Renard, and Baie de Gaspé, and populations of M. edulis (o) in New Richmond and the Magdalen Islands. Experiments were conducted in GrandeRivière $(\mathbf{\Delta})$ 
sensitivity to environmental stress may determine the distribution of these 2 morphologically similar species and which developmental stage would most likely be affected when salinity drops in the field.

\section{MATERIALS AND METHODS}

Rearing procedures. Adult mussels were collected from the intertidal of Rivière-au-Renard and a mussel farm at House Harbour, Magdalen Islands in July 2000 (Fig. 1). The mussels were kept in a tank with flowthrough seawater at 11 to $13^{\circ} \mathrm{C}$ and 27 to $29 \mathrm{ppt}$ salinity for at least $10 \mathrm{~d}$ before being induced to spawn. Pure populations of $M$. trossulus were reported from Rivière-au-Renard (Thomas et al. 2000) and M. edulis from the Magdalen Islands (Tremblay et al. 1998). The individuals selected for spawning were first morphologically screened by shell shape. Only individuals showing typical $M$. edulis and $M$. trossulus shapes (McDonald et al. 1991) were chosen. After spawning, their identities were confirmed using PCR with the primer Glu-5 (Rawson et al. 1996). To obtain gametes and rear early developmental stages of both mussel species, we adopted a procedure from Eyster \& Pechenik (1987). Briefly, 20 individuals were induced to spawn by transferring them from $11-12$ to $23-25^{\circ} \mathrm{C}$ seawater. Within $15 \mathrm{~min}$ about half of the individuals began to release oocytes or sperm. Spawning individuals were transferred to $18^{\circ} \mathrm{C}$ filtered $(1 \mu \mathrm{m})$ seawater, where more gametes were released. Sperm from 3 males and oocytes from 3 females were mixed at a ratio of 20 sperm oocyte ${ }^{-1}$. The fertilized eggs were left undisturbed for $8 \mathrm{~h}$, which is the time required for embryos to develop cilia and swim to the water surface. The swimming embryos were then siphoned into another container. As D-veligers emerged $2 \mathrm{~d}$ after fertilization, water was poured through a $21 \mu \mathrm{m}$ pore mesh. The larvae retained on the mesh were transferred to another container of filtered seawater. Larvae were cultured under gentle aeration at an initial density of 50 larvae $\mathrm{ml}^{-1}$. They were fed Isochrysis galbana (Clone T-Iso) at a concentration of $2.5 \times 10^{4} \mathrm{cells} \mathrm{ml}^{-1}$ and Chaetoceros muelleri (Clone Chgra) at a concentration of $1 \times 10^{4}$ cells ml ${ }^{-1}$. Every $2 \mathrm{~d}$, water and food were renewed. After each water change, 20 larvae were collected for microscopic observation to determine the stage of development.

Expt I: Early development under hyposaline stress. Under favorable conditions (ca. $20^{\circ} \mathrm{C}, 30 \mathrm{ppt}$ ), Mytilus edulis takes approximately $6 \mathrm{~h}$ to develop after fertilization to a swimming embryo, $2 \mathrm{~d}$ from a swimming embryo to a D-veliger, and 1 mo from a D-veliger to an eyed-veliger (Bayne 1965, Strathmann 1987). The effect of lowered salinity on these stages was experi- mentally investigated. Preliminary results (not shown) indicated that juveniles and adults of $M$. edulis and $M$. trossulus were able to survive and grow well at $25 \mathrm{ppt}$. Seawater (27 to $29 \mathrm{ppt}$ ) pumped from $7 \mathrm{~m}$ deep near the Centre Aquicole Marin, Grande-Rivière, Québec was filtered and used in our experiments. The seawater was adjusted using distilled water into 5 salinity treatments $(5,10,15,20$, and $25 \mathrm{ppt})$. The 5 ppt treatment represents the lowest salinity reported from natural habitats of Mytilus species (Remane 1971, Janssen et al. 1999). All experiments were conducted at 18 to $19^{\circ} \mathrm{C}$. The ontogenetic stages were followed until they developed into the next stage or died, except for the eyed-veliger to plantigrade transition, which was allowed to run for $1 \mathrm{wk}$ when ca. $50 \%$ of larvae in the highest salinity treatment had settled. The experiments were carried out in beakers containing $50 \mathrm{ml}$ of seawater, except where noted. There were 3 replicates for each salinity treatment.

For the first experiment (Expt IA), 100 oocytes were pipetted into each beaker and mixed with sperm. The swimming embryos were counted $6,8,12,24,36,48$, and $60 \mathrm{~h}$ after mixing gametes. These data were used to calculate survivorship and the time it took for an oocyte to develop into a swimming embryo (duration of development). A separate stock was established by mixing gametes in a bucket filled with $10 \mathrm{l}$ seawater (filtered to $1 \mu \mathrm{m}$ ) and maintained at 18 to $19^{\circ} \mathrm{C}$ and 27 to 29 ppt. This stock was used to generate different ontogenetic stages for the remaining experiments. Expt IB followed swimming embryos as they developed into the D-veliger stage under the 5 salinity treatments. The D-veligers were counted at 24,48 , and $72 \mathrm{~h}$. Expt IC followed D-veligers as they developed into eyed-veligers under the 5 salinity treatments. At this stage, the larvae were fed with Isochrysis galbana and Chaetoceros muelleri at the concentrations mentioned above. The beakers were checked for eyedveligers after $20 \mathrm{~d}$. The eyed-veligers were counted and removed from the beakers. Expt ID was conducted when ca. 50\% larvae in the stock had developed visible eyes. To facilitate larval settlement, a bundle of polypropylene monofilaments (230 filaments, each filament $3 \mathrm{~cm}$ long with a diameter of $1 \mathrm{~mm}$ ) were placed in the beaker. The filaments were tied at one end with a cable tie and a stainless steel nut weight. Larvae that settled on the filaments were counted after $1 \mathrm{wk}$. These data were used to calculate the percentage of metamorphosed larvae over total number of eyed larvae.

Expt II: Survival of juveniles and adults under hyposaline stress. The sensitivity of juveniles and adults to hyposaline stress was tested. Mytilus edulis from New Richmond and $M$. trossulus from Rivière-auRenard (Fig. 1) were collected from the intertidal region. Juveniles 4 to $6 \mathrm{~mm}$ long, and adults 2.5 to $3.0 \mathrm{~cm}$ 
long, were brought back to the laboratory and acclimated for 1 to $5 \mathrm{wk}$ in a tank with flow-through seawater $\left(11\right.$ to $13^{\circ} \mathrm{C}, 27$ to $\left.29 \mathrm{ppt}\right)$ before being used for the experiment. No mortality occurred during the acclimatization. The experiment was conducted over 2 periods from July 13 to 23, and from August 20 to 30, 2000. On July 13, most individuals had full gonads, while on August 20, all individuals had gonads with only thin layers of gametes. The experiment consisted of the same 5 salinity treatments with 3 replicates of 10 individuals in 11 water. Throughout the experiment, the water was gently aerated and the temperature was maintained at 18 to $19^{\circ} \mathrm{C}$. Isochrysis galbana $\left(2.5 \times 10^{4}\right.$ cells ml $\left.{ }^{-1}\right)$ was fed to the mussels. Water and food were changed every 2 d. Dead individuals, showing characteristic opened shells and whitish decomposing tissue, were discarded. At the end of the $10 \mathrm{~d}$ experiments, sur- vivors were counted. These data were used to calculate survivorship.

Data analysis. The differences among salinity, species, developmental stage, and time treatments were tested by a fixed effects ANOVA model using SAS statistical package (SAS 1988). Normality was examined on residuals using the Univariate Procedure (SAS 1988). Rank transformation (Conover \& Iman 1981, Zar 1996) was applied whenever the normality assumption was violated at $\alpha=0.05$. When significant difference among treatments was detected, multiple comparisons were conducted using the least-square means method (SAS 1988). The significant level in the multiple comparisons was corrected by the number of degrees of freedom (Rice 1989). In Expt I, a 3-factor ANOVA was used to compare the survivorship and duration of development of different stages of the 2 mussel species
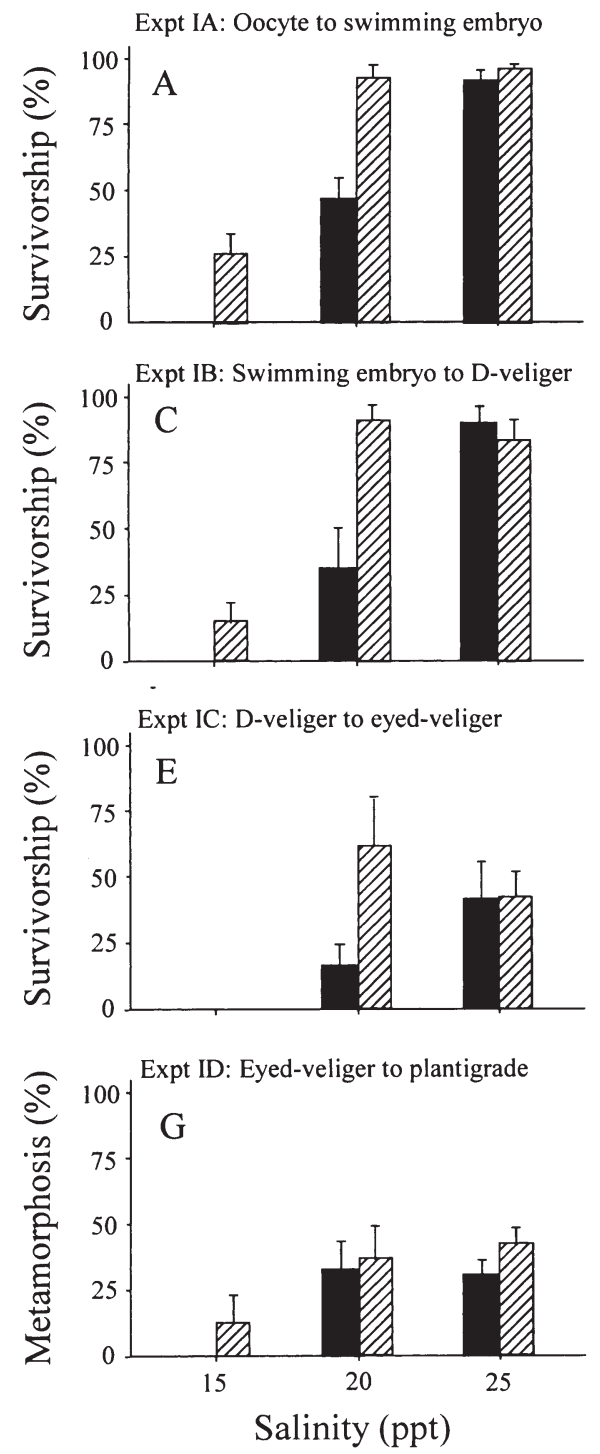
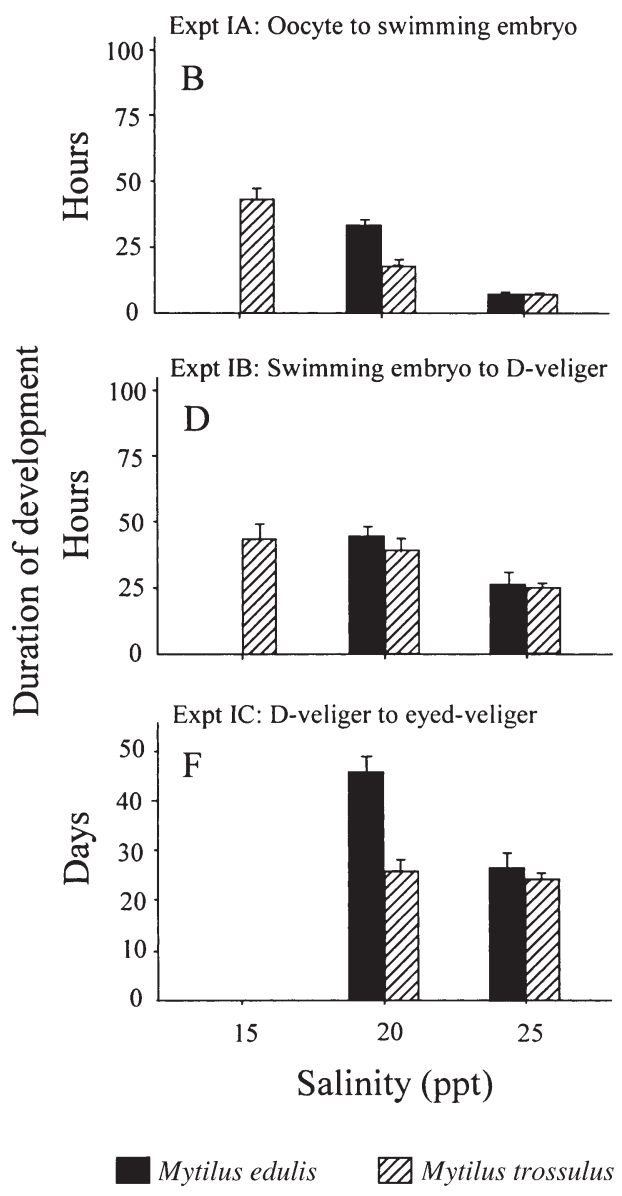

Fig. 2. Mytilus edulis and M. trossulus. Survivorship and duration of development of early ontogenetic stages, and percentage of eyed-veligers metamorphosed under hyposaline stress. Data were plotted as means + standard deviation of 3 replicate cultures. Each replicate started with 100 individuals. At 5 and 10 ppt, all mussels died (data not shown) 
under different salinity treatments, and a 2-factor ANOVA was used to compare the percentage of individuals of the 2 species that metamorphosed under different salinity treatments. In Expt II, a 2-factor ANOVA was applied to compare the survivorship of the adults of the 2 species under the salinity treatments for the experiment conducted from July 13 to 23.

\section{RESULTS}

\section{Expt IA: Oocyte to swimming embryo}

After 60 h, all oocytes that failed to undergo fertilization and cleavage were dead and had disintegrated. Successful development led to embryos covered with cilia that swam geonegatively towards the water surface. Salinity significantly influenced both survivorship and duration of development for both species (Fig. 2A,B, Tables $1 \& 2$ ). At salinities $\leq 10 \mathrm{ppt}$, no oocytes developed into swimming embryos. At $15 \mathrm{ppt}$, none of the Mytilus edulis and only ca. $25 \%$ of $M$. trossulus completed this stage of development. At $20 \mathrm{ppt}$, ca. $47 \%$ M. edulis and $>90 \%$ of $M$. trossulus successfully became swimming embryos. At 25 ppt, $>90 \%$ of oocytes of both species successfully completed the development of this stage. The duration of development was longer as salinity decreased for both species. At $25 \mathrm{ppt}$, swimming embryos were first noted $6 \mathrm{~h}$ after mixing sperm and oocytes. In M. edulis, embryos appeared after $33 \mathrm{~h}$ at $20 \mathrm{ppt}$ to after $7 \mathrm{~h}$ at $25 \mathrm{ppt}$. $M$. trossulus took 44,20 , and $7 \mathrm{~h}$ at 15,20 , and $25 \mathrm{ppt}$, respectively, to complete this stage.

\section{Expt IB: Swimming embryo to D-veliger}

The experiment was run for $72 \mathrm{~h}$, by which time some swimming embryos had formed the first larval shell and become D-veligers. Most embryos unable to complete this stage of development disintegrated, a few were still swimming but deformed and had 1 or 2 protruding clumps of cells. The embryos of both species responded to hyposaline stress in a similar way as the oocyte-swimming stage (Fig. 2C,D, Tables 1 \& 2). Mytilus edulis only developed at 20 and 25 ppt, with a lower percentage of success at 20 ppt (36\%) compared to 25 ppt (91\%). M. trossulus successfully developed at 15 to 25 ppt, with 15, 91, and $84 \%$ of the swimming embryos completing development at 15,20 , and $25 \mathrm{ppt}$, respectively. The duration of development increased with decreasing salinity for both species. D-veligers were first observed after ca. $20 \mathrm{~h}$ into the experiment at $25 \mathrm{ppt}$ for both species. $M$. edulis developed faster at higher salinity and took $45 \mathrm{~h}$ at $20 \mathrm{ppt}$ and $26 \mathrm{~h}$ at $25 \mathrm{ppt}$. M. trossulus required 44 , 39 , and 26 h at 15,20 , and 25 ppt, respectively.

\section{Expt IC: D-veliger to eyed-veliger}

The experiment was run for $50 \mathrm{~d}$. In the 20 and 25 ppt treatments, D-veligers kept swimming. At lower salinities (5 to $15 \mathrm{ppt}$ ), all larvae sank to the bottom of the beaker, closing their larval shells. At 5 ppt, no larvae resumed swimming. About $70 \%$ of larvae at $10 \mathrm{ppt}$ recovered within $30 \mathrm{~min}$ but they were sluggish and swam near the bottom of the beaker. Over $90 \%$ of larvae in $15 \mathrm{ppt}$ took ca. $15 \mathrm{~min}$ to recover and seemed to swim randomly throughout the beaker. Non-swimming larvae lay flat on the bottom and eventually died. Although a significant proportion of larvae at 10 and 15 ppt seemed to recover from the initial shock, these larvae grew slowly, and

Table 1. Three-factor ANOVA results on differences in survivorship and duration of development among salinity $(15,20$, and $25 \mathrm{ppt}$ ), stage (Stage $1=$ oocyte to swimming embryo, Stage $2=$ swimming embryo to D-veliger, Stage $3=$ $\mathrm{D}$-veliger to eyed-veliger), and species ( $M$ ytilus edulis and $M$. trossulus) treatments in Expt IA,B,C. Data from treatments of 5 and 10 ppt were not included in analysis of survivorship due to mortality of entire treatments. Survivors data were not transformed since the residues conformed the normality assumption. Data on duration of development were analyzed only for 20 and 25 ppt treatments since there were no data from 5 and $10 \mathrm{ppt}$, and no data from 4 treatments from 15 ppt. Duration of development data were rank transformed since the normality assumption was violated. $\mathrm{ns}=$ not significant

\begin{tabular}{|lrrrc|}
\hline Source of variation & df & MS & \multicolumn{1}{c|}{$F$} & $\mathrm{p}$ \\
\hline Survivorship & & & & \\
Species & 1 & 4722.685 & 84.81 & 0.0001 \\
Stage & 2 & 6533.407 & 117.33 & 0.0001 \\
Salinity & 2 & 21689.019 & 389.49 & 0.0001 \\
Species $\times$ Stage & 2 & 350.519 & 6.29 & 0.0045 \\
Species $\times$ Salinity & 2 & 2140.574 & 38.44 & 0.0001 \\
Species $\times$ Stage $\times$ Salinity & 8 & 480.546 & 8.63 & 0.0001 \\
Error & 36 & 55.685 & & \\
Duration of development & & & & \\
Species & 1 & 100.000 & 24.66 & 0.0001 \\
Stage & 2 & 1539.000 & 379.48 & 0.0001 \\
Salinity & 2 & 469.444 & 115.75 & 0.0001 \\
Species $\times$ Stage & 2 & 9.333 & 2.30 & 0.1218 (ns) \\
Species $\times$ Salinity & 2 & 44.444 & 10.96 & 0.0029 \\
Species $\times$ Stage $\times$ Salinity & 8 & 19.278 & 4.75 & 0.0057 \\
Error & 24 & 4.056 & & \\
\hline
\end{tabular}


Table 2. Least-square means results on differences in duration of development among salinity, stage, and species treatments in Expt IA,B,C. Stage 1 = oocyte to swimming embryo. Stage $2=$ swimming embryo to D-veliger. Stage $3=\mathrm{D}$-veliger to eyedveliger. Edu $=$ Mytilus edulis. Tro $=M$. trossulus. Significance levels were corrected by the number of degrees of freedom: $\alpha=$ 0.05 for species within stage within salinity comparisons; $\alpha=0.017$ for stage within species within salinity comparisons. Values are arranged in an increasing order from left to right. Groups underlined are not significantly different

\begin{tabular}{|c|c|c|c|c|c|c|c|c|}
\hline \multicolumn{5}{|c|}{$\longrightarrow$ Stage within species within salinity } & \multicolumn{4}{|c|}{ - Species within stage within salinity } \\
\hline \multirow{2}{*}{$\frac{\text { Salinity }}{20}$} & \multirow{2}{*}{$\begin{array}{c}\text { Species } \\
\text { Edu }\end{array}$} & \multicolumn{3}{|c|}{$\longrightarrow$ Stage $\longrightarrow$} & \multirow{2}{*}{$\frac{\text { Salinity }}{20}$} & \multirow{2}{*}{$\begin{array}{c}\text { Stage } \\
\text { Stage } 1\end{array}$} & \multicolumn{2}{|c|}{ Species } \\
\hline & & Stage 1 & Stage 2 & Stage 3 & & & $\underline{\text { Tro }}$ & Edu \\
\hline & Tro & Stage 1 & Stage 2 & Stage 3 & & Stage 2 & Tro & Edu \\
\hline \multirow[t]{4}{*}{25} & Edu & $\overline{\text { Stage } 1}$ & $\overline{\text { Stage } 2}$ & Stage 3 & & Stage 3 & $\underline{\text { Tro }}$ & $\underline{E d u}$ \\
\hline & Tro & $\overline{\text { Stage } 1}$ & $\overline{\text { Stage } 2}$ & $\overline{\text { Stage } 3}$ & 25 & Stage 1 & $\overline{E d u}$ & $\overline{\text { Tro }}$ \\
\hline & & & & & & Stage 2 & Tro & Edu \\
\hline & & & & & & Stage 3 & Tro & Edu \\
\hline
\end{tabular}

eventually died after 1 to 2 wk. There was successful development in the 2 highest salinity treatments (Fig. 2E,F, Tables $1 \& 2$ ). The percentage of Dveligers that completed development (ca. 40\%) and the duration of development (24 to $26 \mathrm{~d}$ ) at $25 \mathrm{ppt}$ were similar for the 2 species. At $20 \mathrm{ppt}$, however, there were significant differences in both survivorship and duration of development. In Mytilus edulis, $16 \%$ survived and it took $45 \mathrm{~d}$ for development, compared to $M$. trossulus with $61 \%$ survival and $26 \mathrm{~d}$ for development.

\section{Interactions among factors in Expt IA,B,C}

Significant species $\times$ stage $\times$ salinity interaction was detected in the survivorship data (Tables 1 \& 2). For Mytilus edulis, no individuals survived at $15 \mathrm{ppt}$ and survival was lower at 20 ppt compared to that at $25 \mathrm{ppt}$ for the 3 developmental stages tested. For $M$. trossulus, the survival at 15 ppt decreased from approximately $25 \%$ at oocyte to swimming embryo stage to none at D-veliger to eyedveliger stage. There were no significant differences between the 20 and 25 ppt treatments on the survival for each of the 3 stages.

Significant species $\times$ stage $\times$ salinity interaction was also detected for duration of development data (Tables 1 \& 2). It took significantly longer to complete the later stages of development for both species. Compared to the 25 ppt treatment, Mytilus edulis took a significantly longer time to complete all 3 stages at 20 ppt. This lag at low salinity was also found in $M$. trossulus for the oocyte to swimming embryo stage and swimming embryo to Dveliger stage. However, there was no significant difference in development time between the 2 salinity treatments at D-veliger to eyed-veliger stage of $M$. trossulus.

\section{Expt ID: Metamorphosis of eyed-veligers}

The salinity level significantly affected metamorphosis. None of the eyed-veligers at salinities $\leq 10 \mathrm{ppt}$ successfully metamorphosed over the $7 \mathrm{~d}$ experiment (Fig. 2G, Table 3). At 15 ppt, no Mytilus edulis and only $13 \%$ of $M$. trossulus completed this stage of development, and there was no significant difference between species. At $20 \mathrm{ppt}$, a slightly lower percentage of $M$. edulis successfully became plantigrades (32\%) compared to $M$. trossulus (37\%). Even at $25 \mathrm{ppt}$, only low percentages of eyed-veligers metamorphosed into plantigrades: $30 \%$ for $M$. edulis and $42 \%$ for M. trossulus. There were no significant interactions between salinity and species on percent metamorphosis, which indicates that both species had the same response to

Table 3. Summary of 2-factor ANOVA and least-square means results on difference in percent eyed-veligers metamorphosed among salinity $(15,20$, and $25 \mathrm{ppt}$ ) and species (Mytilus edulis and M. trossulus) treatments in Expt ID. Data were not transformed. Least-square means results are arranged in increasing order from left to right. Significance level is corrected by the number of degrees of freedom: $\alpha=0.05$ for comparison between species, and $\alpha=0.017$ for comparison among salinity treatments. Groups underlined are not significantly different. Edu $=$ M. edulis. Tro $=M$. trossulus. $\mathrm{ns}=$ not significant

\begin{tabular}{|c|c|c|c|c|}
\hline $\begin{array}{l}\text { ANOVA } \\
\text { Source of variation }\end{array}$ & df & MS & $F$ & $\mathrm{p}$ \\
\hline Species & 1 & 420.500 & 5.89 & 0.0319 \\
\hline Salinity & 2 & 1714.500 & 24.02 & 0.0001 \\
\hline Species $\times$ Salinity & 2 & 32.167 & 0.45 & 0.6476 (ns) \\
\hline Error & 12 & 71.389 & & \\
\hline \multicolumn{5}{|l|}{ Least-square means } \\
\hline Species & $\underline{\text { Edu }}$ & Tro & & \\
\hline Salinity & 15 & 20 & & \\
\hline
\end{tabular}


the salinity with a higher percent metamorphosis at higher salinities.

\section{Expt II: Survival of juvenile and adult mussels}

In the experiment conducted from July 13 to 23 (Expt IIA), both species responded similarly to salinity treatments, with significant differences between juvenile and adult mussels (Fig. 3, Table 4). All individuals closed their shells when placed in 5 ppt water. By Day 4 there were dead individuals, and on Day 6 there were no survivors. At 10 ppt about half the adults started to release gametes within $3 \mathrm{~h}$. When spawning occurred in a beaker, the mussels were transferred to fresh seawater to avoid resulting poor water quality. The shells of individuals that had spawned remained ajar, and by Day 6 these were dead. Other adults in the same treatment resumed water pumping activity within $6 \mathrm{~h}$, produced
Table 4. Summary of 2-factor ANOVA and least-square means results on differences in survivorship among salinity $(10,15,20$, and 25 ppt) and species (Mytilus edulis and $M$. trossulus) treatments for the adults in Expt IIA. Data from the juveniles for the same experiment and the juveniles and adults in Expt IIB were not subjected to statistical analysis due to either the mortality of entire treatment at 5 ppt or $>93 \%$ survival at $\geq 10$ ppt. Data were rank transformed. Least-square means results are arranged in increasing order from left to right. Significance level is corrected by the number of degrees of freedom: $\alpha=0.008$ for comparison among salinity treatments. Groups underlined are not significantly different. Edu $=M$. edulis. Tro $=M$. trossulus. $\mathrm{ns}=$ not significant

\begin{tabular}{|c|c|c|c|c|c|}
\hline $\begin{array}{l}\text { ANOVA } \\
\text { Source of variation }\end{array}$ & df & & MS & $F$ & $\mathrm{p}$ \\
\hline Species & 1 & & 1.500 & 0.67 & $0.4252(\mathrm{~ns})$ \\
\hline Salinity & 3 & & 322.028 & 143.79 & 0.0001 \\
\hline Species $\times$ Salinity & 3 & & 0.528 & 0.24 & $0.8702(\mathrm{~ns})$ \\
\hline Error & 16 & & 2.240 & & \\
\hline \multicolumn{6}{|l|}{ Least-square means } \\
\hline Salinity & $\underline{10}$ & $\underline{15}$ & $20 \quad 25$ & & \\
\hline
\end{tabular}

feces and secreted byssal threads that caused clumping. Among the juveniles about $50 \%$ climbed up the beaker walls using their feet and attached after secreting byssal threads, although all adults remained on the bottom. There was differential mortality between juve-

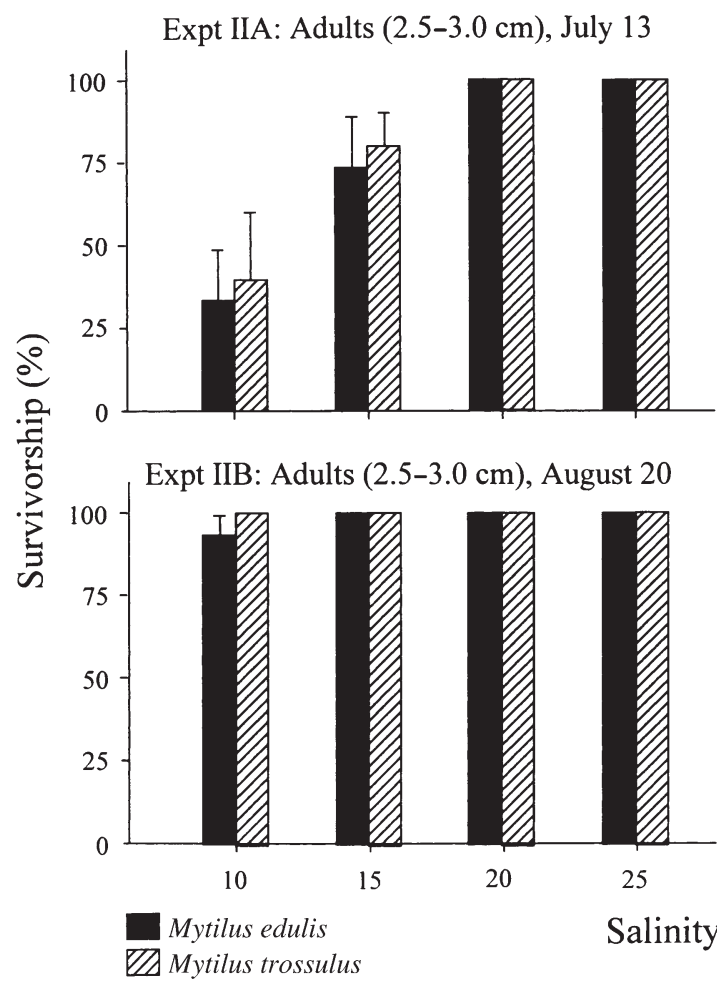

Expt IIA: Juveniles $(0.4-0.6 \mathrm{~cm})$, July 13

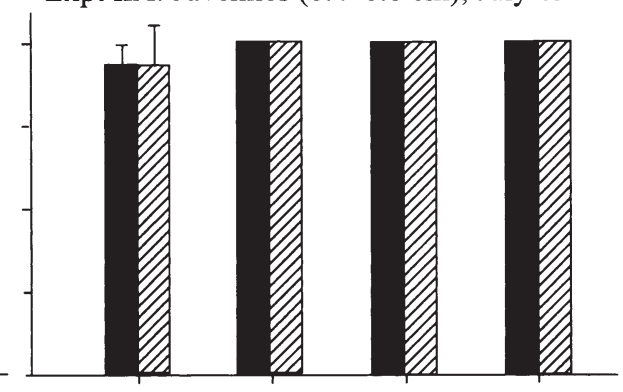

Expt IIB: Juveniles $(0.4-0.6 \mathrm{~cm})$, August 20

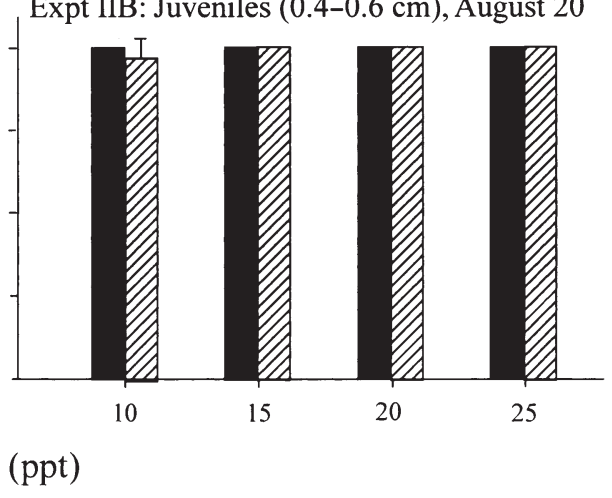

Fig. 3. Mytilus edulis and M. trossulus. Survivorship of juvenile and adult mussels under hyposaline stress. The experiment was performed for 10 d over 2 periods of time (July 13 to 23 and August 20 to 30, 2000), using mussels collected in early July and held at 11 to $13^{\circ} \mathrm{C}$ and 27 to 29 ppt salinity. On July 13, most individuals had full gonads. By August 20, all individuals had gonads with only thin layers of gametes. Data were plotted as means + standard deviation of 3 replicate cultures. Each replicate started with 10 individuals. At 5 ppt, all mussels died (data not shown) 
niles $(<7 \%)$ and adults ( $>60 \%)$. At $15 \mathrm{ppt}$, all juveniles survived over the $10 \mathrm{~d}$. Some adults that had spawned were able to resume water pumping and defecation activities and produce byssal threads, resulting in a higher survival (73 to $80 \%$ ) compared to the $10 \mathrm{ppt}$ treatments. At 20 to $25 \mathrm{ppt}$, all juveniles and adults survived through the experiment.

In the August 20 to 30 experiment (Expt IIB, Fig. 3), the juveniles responded to salinity treatments in the same way as those in Expt IIA. All the adults of both species had spent gonads in the beginning of the experiment and suffered only 0 to $7 \%$ mortality at $10 \mathrm{ppt}$ and no mortality at 15 to $25 \mathrm{ppt}$. All survivors exhibited normal feeding, defecation, byssal thread production and water pumping.

\section{DISCUSSION}

Our finding that the early developmental stages are more sensitive to low salinity than juvenile and adult stages for both mussel species matches the general picture of salinity tolerance in Mytilus derived from various studies at the fertilization to larval stage (Bayne 1965), larval stage (Hrs-Brenko \& Calabrese 1969), and adult stage (Remane 1971). However, some differences were noted. Remane (1971) reported that mussels (likely $M$. trossulus) were found at sites with salinity as low as 4 to 5 ppt in the inner Baltic Sea. None of our juveniles or adults survived for more than $6 \mathrm{~d}$ at $5 \mathrm{ppt}$. The difference may be that 4 to $5 \mathrm{ppt}$ is the lower salinity limit found in the bottom water of the inner Baltic Sea, where the mussels were collected. In estuaries salinity fluctuates following a tidal cycle, usually incoming tidal water pushes the higher salinity water further upstream, and outgoing tidal water causes the higher salinity water to move out towards the ocean. These mussels might thus have experienced salinities higher than 4 to 5 ppt during high tides and suffered less than those in our experiment, which were submerged continuously at 5 ppt until death. This difference in salinity tolerance between the 2 populations could also be the result of local adaptation. Some $M$. trossulus populations would show slight differences in salinity tolerance, following a different adaptive process. Hrs-Brenko \& Calabrese (1969) found that at salinity as low as $15 \mathrm{ppt}$ growth of $M$. edulis larvae was still over $50 \%$ of the maximum. We found no $M$. edulis larvae completing development at 15 ppt. This difference may be explained by the different experimental protocols. Hrs-Brenko \& Calabrese terminated their experiment when larvae in the fastest growing treatment reached settling size, and greater mortality in other treatments might have occurred had the larvae been followed longer. As mentioned earlier, Bayne
(1965) probably reported results for both species of mussels. For the adults collected from Anglesey, which should be $M$. edulis, the development from fertilization to trochophore stage occurred only at 30 to $40 \mathrm{ppt}$ (Bayne 1965). We found that development of $M$. edulis from oocyte to D-veliger was quite successful at a lower salinity ( $25 \mathrm{ppt}$ ). Only at $\leq 20 \mathrm{ppt}$ did oocytes develop poorly. There is evidence that the $M$. edulis populations in Europe differ from those in Atlantic Canada in a number of enzyme loci (Varvio et al. 1988). Behavioral differences between the mussels from the 2 sides of the Atlantic have not been reported. It is not known whether the discrepancy between our results of salinity tolerance and Bayne's was due to genetic differences or differences in conditions experienced by adults, which may influence success in embryonic or larval stages of invertebrates (review by Bayne 1976, Qiu \& Qian 1999). The spawners used by Bayne were held at 30 to $32 \mathrm{ppt}$, while our stock was conditioned at 27 to $29 \mathrm{ppt}$. Although it is possible that the slightly lower acclimation salinity in our mussels may have contributed to the lower salinity threshold for successful development to D-veligers, further study is needed to determine the degree of intra- and interpopulation variation in tolerance to environmental stress and the relative contribution of environment and genetic factors to these variations.

Genetic studies have shown resistance to hyposaline stress associated with the genotype of the adult mussel. The frequency of the Lap ${ }^{94}$ locus in Mytilus edulis decreased with the decline of salinity from the Atlantic Ocean to inner Long Island Sound (Koehn et al. 1976). Demographic studies (Koehn et al. 1980, Hilbish 1985) indicated that small individuals from the sound tended to have a $L a p^{94}$ frequency similar to that of the oceanic populations, while for large individuals, this allele frequency was much lower. These authors proposed that larvae with typical oceanic Lap frequency enter the sound during summer and that settled mussels with the $L a p^{94}$ allele locus subsequently disappear after selective mortality in the estuary. We found that when reproductive mussels were submerged in low salinity waters, a significant proportion of them released gametes within a short period. Some (at $15 \mathrm{ppt}$ ) or all (at $10 \mathrm{ppt}$ ) of these spawning adults died several days later. This hyposalinity related mortality in reproductive adults might affect the abundance and demographic structure of wild mussel populations. Since we did not conduct the Lap analysis on our mussels, we do not know whether this salinity-related mortality was associated with the reduction of $L a p^{94}$ frequency. But if this mortality were related to the individual genotype at the $\mathrm{Lap}^{94}$ locus, our results would support the theory of genotypic selection against large mussels by indicating that selection may occur during the reproductive season. 
In response to a sudden drop of salinity, bivalves usually withdraw their body and close their shells, thereby maintaining the pallial fluid in a hyperosmotic state for a period of time. In the field, such shell closure behavior may offer the veligers a degree of protection by causing them to sink into deeper waters, which are often of higher salinity (Huntsman et al. 1954, Krauel 1975). This shell closure behavior may also allow activation of intracellular mechanisms to regulate concentrations of amino acids as in adult bivalves (Bayne et al. 1976). When a bivalve resumes normal activities, the salt content of its body fluids decreases until reaching isosmosis or a lethal limit. The veligers, juveniles and adults of both Mytilus edulis and M. trossulus showed shell closure behavior. In the veliger stage, recovery from initial hyposaline shock was indicated by resumption of swimming and feeding. Veligers of both species were able to recover from the initial hyposaline shock even at 10 ppt. However, none of the veligers at 10 and $15 \mathrm{ppt}$ were able to complete larval development and all died within 1 to 2 wk. Even at 20 and 25 ppt, where the larvae resumed swimming immediately after introduction into the culture beakers, less than $41 \% \mathrm{M}$. edulis and $61 \%$ M. trossulus completed larval development. Our results suggest that normal swimming behavior may not be a reliable indicator of whether a larva can complete development. Future studies of mussel larvae should use other parameters such as length or height increment to assess larval fitness.

Despite the limitations inherent to laboratory experiments, this study showed that during early development Mytilus edulis was more sensitive to hyposalinity than $M$. trossulus. Such disparity may explain why only $M$. trossulus is found close to several river mouths along the Gaspé Peninsula. The $M$. trossulus population sampled at Rivière-au-Renard is approximately only $0.3 \mathrm{~km}$ from the river mouth of Rivière-au-Renard (Thomas et al. 2000) and over the summer settlement months experienced 15 to 20 ppt salinities (weekly data from July 6 to August 10, 2000, data not shown). Although the potential larval supply from the Gulf of St. Lawrence should consist of both mussel species given that the open water is only $0.4 \mathrm{~km}$ from the river mouth, our experimental results indicate that only the larvae of $M$. trossulus may survive over this salinity range. The larvae of $M$. edulis that arrive at the site are likely to die, or are unable to undergo metamorphosis. At Cap-Noir, which is $1.3 \mathrm{~km}$ from the mouth of the Rivière-au-Renard in the open water, both mussel species are found, with a ratio of $M$. edulis to $M$. trossulus of 1 to 9 (Thomas et al. 2000).

In summary, our data show that only in the early ontogenetic stages is Mytilus edulis less tolerant to low salinity than $M$. trossulus. This difference between the 2 species suggests that selective mortality of early stages, but not of juveniles or adults of $M$. edulis determines the persistence of the pure populations of $M$. trossulus in some river mouths in Québec. We also found that reproductive adult mussels become vulnerable to hyposalinity and we suggest that selection by low salinity may influence the abundance and size structure of wild mussel populations.

Acknowledgements. We thank B. Myrand, V. Moreau and A. Moreau for collecting mussels, S. Bourget and S. Belvin for technical support, L. Lapointe for statistical consultation, V. Moreau for providing salinity data and performing PCR analyses, K. Freeman for assistance with the literature search, $\mathrm{M}$. Cusson for critically reading the manuscript, and C. Lovejoy for linguistic improvement. This project was supported by a MAPAQ and DFO grant to E.B. and R.T. This paper is a contribution to the Groupe Interuniversitaire de Recherches Océanographiques du Québec.

\section{LITERATURE CITED}

Bayne BL (1965) Growth and the delay of metamorphosis of the larvae of Mytilus edulis (L.). Ophelia 2:1-47

Bayne BL (1976) The biology of mussel larvae. In: Bayne BL (ed) Marine mussels: their ecology and physiology. Cambridge Univ Press, Cambridge, p 81-120

Bayne BL, Widdows J, Thompson RJ (1976) Physiology II. In: Bayne BL (ed) Marine mussels: their ecology and physiology. Cambridge Univ Press, Cambridge, p 207-260

Conover WJ, Iman RL (1981) Rank transformation as a bridge between parametric and nonparametric statistics. Am Stat 25:124-129

El-Sabh MI (1976) Surface circulation pattern in the Gulf of St. Lawrence. J Fish Res Board Can 33:124-138

Eyster LS, Pechenik JA (1987) Attachment of Mytilus edulis L. larvae on algal and byssal filaments is enhanced by water agitation. J Exp Mar Biol Ecol 114:99-110

Gosling EM (1992) Systematics and geographic distribution of Mytilus. In: Gosling EM (ed) The mussel Mytilus: ecology, physiology, genetics and culture. Elsevier Science Publishers, Amsterdam, p 1-20

Hilbish TJ (1985) Demographic and temporal structure of an allele frequency cline in the mussel Mytilus edulis. Mar Biol 86:163-171

Hrs-Brenko M, Calabrese A (1969) The combined effects of salinity and temperature on larvae of the mussel Mytilus edulis. Mar Biol 4:224-226

Huntsman AG, Bailey WB, Hachey HB (1954) The general oceanography of the Strait of Belle Isle. J Fish Res Board Can 11:198-260

Innes DJ, Comesaña AS, Toro JE, Thompson RJ (1999) The distribution of Mytilus edulis and M. trossulus at spat collection sites in Newfoundland. Bull Aquacult Assoc Can 99-3:22-23

Janssen F, Schrum C, Backhaus JO (1999) A climatological data set of temperature and salinity for the Baltic Sea and the North Sea. Dtsch Hydrogr Z Suppl 9:1-245

Koehn RK (1991) The genetics and taxonomy of species in the genus Mytilus. Aquaculture 94(2/3):125-145

Koehn RK, Milkman R, Mitton JB (1976) Population genetics of marine pelecypods. IV. Selection, migration and genetic differentiation in the blue mussel Mytilus edulis. Evolution 30:2-32

Koehn RK, Newell RIE, Immermann F (1980) Maintenance of 
an aminopeptidase allele frequency cline by natural selection. Proc Natl Acad Sci USA 77:5385-5389

Koehn RK, Hall JG, Innes DJ, Zera AJ (1984) Genetic differentiation of Mytilus edulis in eastern North America. Mar Biol 79:117-126

Krauel DP (1975) The physical oceanography of the Bras d'Or Lakes, 1972-1974. Fish Mar Serv Res Dev Tech Rep 570, Fisheries and Marine Service, Research and Development Directorate, Fisheries and Oceans Canada, p 370

Mallet AL, Carver CE (1999) Maritime distribution and commercial production performance of Mytilus edulis and Mytilus trossulus. Bull Aquacult Assoc Canada 99-3:7-13

McDonald JH, Seed R, Koehn RK (1991) Allozymes and morphometric characters of three species of Mytilus in the northern and southern hemispheres. Mar Biol 111:323-333

Pechenik JA (1990) Delayed metamorphosis by larvae of benthic marine invertebrates: Does it occur? Is there a price to pay? Ophelia 32:63-94

Qiu JW, Qian PY (1999) Tolerance of the barnacle Balanus amphitrite amphitrite to salinity and temperature stress: effects of previous experience. Mar Ecol Prog Ser 188: 123-132

Rawson PD, Joyner KL, Meetze K, Hilbish TJ (1996) Evidence for intragenic recombination within a novel genetic marker that distinguishes mussels in the Mytilus edulis species complex. Heredity 77:599-607

Remane A (1971) Ecology of brackish water. In: Remane A, Schlieper C (eds) Biology of brackish water. Wiley Interscience, New York, p 1-210

Rice WR (1989) Analyzing tables of statistical tests. Evolution 43:223-225

Editorial responsibility: Otto Kinne (Editor), Oldendorf/Luhe, Germany
SAS (1988) SAS/STAT user's guide, release 6.03 edition. SAS Institute, Cary, NC

Strathmann MF (1987) Reproduction and development of marine invertebrates of the northern Pacific coast. University of Washington Press, Seattle

Theisen BF (1978) Allozyme clines and evidence of strong selection in three loci in Mytilus edulis L. (Bivalvia) from Danish waters. Ophelia 17:135-142

Thomas B, Tremblay R, Turcotte MP (2000) Distribution de Mytilus edulis et Mytilus trossulus dans les régions maritimes du Québec entre 1996 et 1998 et avec références à la situation dans les provinces maritimes. Ministère de l'Agriculture, des Pêcheries et de l'Alimentation, Québec. Direction de l'innovation et des technologies. Cahier d'information 138, p 1-37

Tremblay R, Myrand B, Sévigny JM (1998) Genetic characterization of wild and suspension-cultured blue mussels (Mytilus edulis Linneaus, 1758) in the Magdalen Islands (southern Gulf of St. Lawrence, Canada). J Shellfish Res 17:1191-1202

Väinölä R, Hvilsom MM (1991) Genetic divergence and a hybrid zone between Baltic and North Sea Mytilus populations (Mytilidae: Mollusca). Biol J Linn Soc 43: $127-148$

Varvio SL, Koehn RK, Väinölä R (1988) Evolutionary genetics of the Mytilus edulis complex in the North Atlantic region. Mar Biol 98:51-60

Widdows J (1991) Physiological ecology of mussel larvae. Aquaculture 94:147-163

Zar JH (1996) Biostatistical analysis, 3rd edn. Prentice-Hall, New York

Submitted: December 22, 2000; Accepted: August 8, 2001 Proofs received from author(s): February 8, 2002 